\title{
Petronius' Giton: Gender and Genre in the Satyrica
}

John F. Makowski

Loyola University Chicago, jmakow1@luc.edu

Follow this and additional works at: https://ecommons.luc.edu/classicalstudies_facpubs

Part of the Classics Commons

\section{Recommended Citation}

Makowski, John F. "Petronius' Giton: Gender and Genre in the Satyrica." In Narrating Desire Eros, Sex, and Gender in the Ancient Novel. Berlin, Boston: De Gruyter, 2012. http://dx.doi.org/10.1515/

9783110282047.223

This Book Chapter is brought to you for free and open access by the Faculty Publications and Other Works by Department at Loyola eCommons. It has been accepted for inclusion in Classical Studies: Faculty Publications and Other Works by an authorized administrator of Loyola eCommons. For more information, please contact ecommons@luc.edu.

\section{(c) $\odot \odot$}

This work is licensed under a Creative Commons Attribution-Noncommercial-No Derivative Works 3.0 License. (C) De Gruyter, 2012. 


\title{
Petronius' Giton: Gender and Genre in the Satyrica
}

\author{
John F. Makowski
}

\begin{abstract}
Encolpius, the narrator of the novel, exhibits an obsession with literature that impels him to interpret his world througl the lens of earlier classics. Thus, Giton embodies analogues to both the heroes and the heroines of epic and tragedy often in the context of the picaresque. The fluidity of his gender toles mirrors the novel's fluctuation among the genres of literature. As backdrop to the Satyrica's play with gender and genre stands Nero's art of performing in both masculine and feminine roles on the Roman stage.
\end{abstract}

The sexual universe of Petronius' Satyrica is almost without parallel in world literature, and so, not surprisingly, both because of its unabashed openness and its manifold variety of erotic experience, the novel has evoked the extremes of reactions from prurient exploitation to bowdlerization and censorship. ${ }^{1}$ Contemporary criticism, freed from Victorian prudery and illuminated by studies in gender and sexuality, particularly male-male sexuality, has contributed much to the understanding of the erotic dynamics of the Satyrica. ${ }^{2}$ Still, however, whether viewed through modern distinctions of 'heterosexual' or 'homosexual' or in terms more appropriate for ancient experience like 'active' and 'passive', the erotic dynamics of the narrative defy easy classification. This is especially true in those episodes where the carnival of sex intersects with the world of literature and where roles of gender interplay with the conventions of

1 For a discussion of the novel's sexual themes see Sullivan 1968a, 232-53, where he treats issues like obscenity and what he calls 'the pornographic tradition', and, for a recent overview of the novel's own sexual history, see Richlin's comments $(2009,96-99)$ on 'outlaw sex'.

2 The essential studies on male-male sexuality are those of Richlin 1993, Williams 1999 and Hubbard 2003. Readers of Petronius in translation can find a concise, informative essay on ancient sexuality in the edition by Ruden $2000,144-49$. 
genre. ${ }^{3}$ For alongside the question of gender in the novel is the equally complicated issue of literary typology. Not only does the work itself defy easy classification into a known genre of ancient literature, but also its dense inter-textual form, with its congeries of allusions, its parody of literary antecedents, and its own ever shifting tone makes for a work remarkably protean in its elusiveness."

'Gender dissonance' is a term used by Marilyn Skinner in her studies of the construction of male sexuality in the poetry of Catullus." By gender dissonance Skinner means that "in virtually every literily genre, boundaries between "male" and "fenuale" as essential categories of psychosexual identity fluctuate wildly and eventually break down'. In the world of this novel we see the total obliteration of all boundaries such as homosexual and heterosexual - to use modern citegories but also the blurring of active and passive, and, in fact, of mile and female. The principal characters are basically but not exclusively homosexual fratres whose adventures entail triangular affairs in almost every conceivable combination and permutation: Encolpius, Giton and Ascyltus form one triangle, Encolpius, Lichas, and Tryphaena another, and in all probability Encolpius, Giton and Tryphaena still another -- just to mention a few of the possibilities." All noms of sexual protocol are thrown into confusion by many of the novel's characters, most notably by Eumolpus - shamelessly aggressive predator of Giton and of the Pergamene boy but later at Croton equally aggressive with the legacy hunter's daughter whom he enjoys nonetheless in homosexual fashion. The novel's sexual carnival, however, transcends priapic crudity because it is redeemed, as it were, by the brilliance of its play with antecedent literature. For in the Salyrica we are dealing with a supremely literate work, whose narrator from episode to episode exhibits his conversance with a vast amount of Greek and Roman literature from Homer down to his contemporaries in Petronian Rome. So, to borrow a phrase from Eumolpus' prescription for the writer of epic at 118.4. Encolpius himself

3 For a neat classification of sexual behaviors in antiquity see Parker 1047, especially his grid illustrating the complementarities of coitus $(45)$.

4 Adding to the discussion of whether the Satyrion is a novel, a satire, a Menip. pean satire, or a mime or rather a parody of other genres like epic, is Jensom 2004, who, on the basis of what he calls namotio in persomis ("personal recollection'), makes a strong case for reading the Satyrion as a Milesian talc.

6 Skinner 1997a, 129-50.

6 The dynamics of the homosexual configurations are well analyzed by Richartson $1984,112-15$. See also Richlin $2009,84-89$. 
possesses a mens ingenti flumine litterarum inundata, 'a mind thoroughly steeped in the currents of Greek and Roman literature'; or to cite the apt term of a modern critic, he is a 'mythomanic narrator'.' That mania for literature is an all-consuning obsession that leads him to interpret the world around him (people, places, and events) through the lens of epic, tragedy, comedy, Platonic dialogue, rhetorical declamation, and romance novel. ${ }^{8}$ Yet, although the narrator is steeped in the liternture of the high-minded classics, the world he finds himself in is often that of low-life prostitutes, thieves, charlatans, and con artists - the world of the picaresque. Thus the novel's juxtaposition of the sublime genres of Greco-Roman literature alongside the world of the picaresque makes for a work almost unique in its incongruity.

At the center of the Satyrica's sexual carnival stands Citon. To his charms no male or female is impervious; his conquests include the two principals, but also Eumolpus, Quartilla, Tryphaena, and even the sailors on Lichas' ship. So, we may ask, who or what is Giton? Obviously, he is the frater of Encolpius but also the object of sexual desire for Ascyltus, Eumolpus, and, in all likelihood, Tryphaena. At Sat. 97.2, we learn that he is: puer. . . annorum circa XVI, crispus, mollis, formosus, nomine Giton ('a boy of about sixteen years, curly-haired, soft, beautiful, named Giton'). The description, with its references to youth, curly hair, effeminacy, and beauty, indicates in so many words that (riton belongs to the class of paidika or pueri delicati such as those celebrated in Strato's Musa Puerilis or in the poetry of Catullus and Vergil and in the plastic arts. ${ }^{9}$ As for social class, it is tempting here to agree with Courtney, on the basis of Sat. 104, that Giton, like Encolpius, was a fingitious, a runaway slave from his master Lichas." Even though Giton's role in the novel is largely that of the paidika, his activity in the sexual sphere is not limited to the role of boy pathic because, of course, he illustrates his heterosexual side by deflowering Pannychis, apparently during the

7 Conte 1996a, 37-72 offers an insightful discussion of Encolpius' litcrary obsessions in his chapter entitled 'The Mythomaniac Narrator and the Ionging for the Sublime'.

8 On the influence of Greek literature see J. R. Morgan 2m149, 32 -..47, for expe cially useful discussion of the debt of the Satyrica to Homer. Plate, and the Greek novel. On some Roman influence see (. Panayotakis $21(1)$, $48 \times(64$. Jensson 2004, 50-83 uses the tems 'scripted memories' and 'compulsive lin". guistic affliction' to describe what he calls 'the desultory voice of Encolpius'.

9 On the latter, see recently Pollini 1999.

10 Courtney 2001, 48-49; see also Richlin 2009, 86-87. 
lost narrative of Quartilla's orgy. That Giton, mollis and youthful, should go from gratifying adult males to engaging with females should cone as no surprise in the pansexual carnival of the Satyrica, where gender identity and the distinction between active and passive break down not just in the case of Giton but in other characters including Encolpius. Trimalchio too, it will be remembered, as a slave had cuckolded his master while serving as his catamite (75). Bisexual activity for both (iton and Trimalchio is, of course, a feature of the liminal stage of adolescence.

The sexually polyvalent Giton is the frater of the very literute Encolpius, whose reaction to Giton's psychosexual behavior elicits both masculine and feminine analogies to the heroes and heroines of (irecoRoman literature. At times, Giton plays the epic hero from Homer or from Vergil, at others he becomes the 'heroine' from tragedy or epic, and at times he is simultaneously both under a multiple layer of literary reminiscences. Both obvious and silly is the scene at Silt. 98 where Giton clings to the bug-infested mattress, and we hear that he was literally Ulixen, cui vel esuriens Cyclops potuisset parcere ("a Ulysses that even a hungry Cyclops could have spared'). "The citation of the lofty Homeric epic in the context of the squalor of the inn is typical of Petronius' humorous technique. We remember too that ifter 'Trimalchio's dinner it was Giton who had guided his companions to the infatmous inn and that he did so with clear echoes of Ariadne, having marked the labyrinthine way back with chalk. ${ }^{11}$

While Giton is at one time Ulysses and at another Ariadne, it is in the taberna episode where the play of gender and genre on the part of Petronius is most brilliant. For here when Encolpius and Ascyltus quarrel over the boy and threaten to divide him up physically, Giton exhibits both male- and female-gendered behaviors with allusions to the heroes and heroines of epic and tragedy. ${ }^{12}$ Thus, at $8(0.4$ Citon, in a surprising

11 Sat. 79.4: expliciti acumine Gitonis sumus. prudens enim pher, cum luce ctitum dara

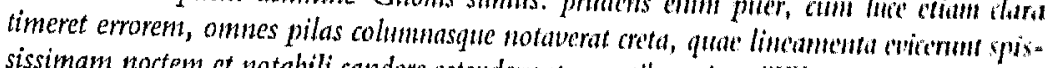
sissimam noctem et notabili candore ostenderunt cranuibus piam ("We were at list suved by Giton's cleverness. Fearing getting lost even during the daymetime, he had thoughtfully marked with chalk all the posts and columns'). (i. Pamayotakis 2009,54 also discerns in Giton an allusion to the Sibyl when he throws a sop to a dog at 72.9 .

12 Rankin 1997, 23 sees Giton as a 'femme fatale' who 'applied moral hlackmail. by threatening to kill himself or offering hinself to be killed when rows which 
show of erudition for one of his age and class, refers to the rivals for his affections as Thebanum par, signaling that the humilis taberna is the setting for the tragedy of Eteocles and Polyneices, fratres far removed from the likes of Encolpius and Ascyltus. Giton's appeal is cast in the diction of high tragedy: quod si utique ... facinore opus est, nudo ecce ingulum, convertite huc manus, imprimite mucrones. ego mori debeo, qui amicitiae sacramentum delevi ('But if there must be a crime, look, I bare my throat, turn here your hands, use your swords. I am the one who should die, the one who wrecked the onth of friendship'). Obviously, Giton with this poetic and rhetorical outburst has become that notable queen of tragedy, Jocasta. ${ }^{1.3}$ Also, along with the allusion to Aeschylus and Seneca, it is possible, too, that we are meant to recall Livy and his account of the Sabine women interposing themselves between their fathers and husbands. The layers of literary allusion, however, also include Vergil, who stands behind both Seneca's tragedy and Petronius' parody of it. For Giton as Jocasta simultaneously evokes Nisus of Aeneid 9, lover of Euryalus, and his heroic act of self-sacrifice for his boy-love. ${ }^{14}$ Giton's words recall those of Nisus at Acneid 9.427-29: me, me adsum qui feci, in me convertite ferrum / o Rutuli! mea fraus omnis, nihil iste nec ausus nec potuit ("Turn your swords on me, o Rutulians, on me who did the deed. The treachery is all mine. The boy dared nothing, nor could he have'). Yet Giton, for all his solemn diction borrowed from epic and tragedy, is no Nisus, no Jocasta, because he totally undermines any idea of self-sacrifice when he violates the amicitiac sacramentum by choosing Ascyltus over Encolpius. Thus, in a brillinnt piece of legerdemain, Petronius slides from tragedy and epic straight into the world of nime, as is made clear by the verses at 80.9. Panayotakis has pointed out that the episode in the tavern is modeled on the adultery mime;" here, as he puts it, "Giton who plays the wife, when asked to choose between his 'husband' and his 'lover' prefers to follow the latter in a bold and most amusing manner: qui ne deliberavit quidem, ut. viderctur cunctatus, vernm statim ab extrema parte verbi consurrexit $\langle e t\rangle$ fratrem Ascylton elegit ("with these words, he, without even stopping to pretend to think about it, chose Ascyltus as his boyfriend')'.

he has engineered flare up more fiercely than is suitable to his purpose of playing off one of the friends against the other'.

13 Conte 1996a, 80)-81 has an acute discussion of Giton as Jocasta.

14 See Conte 1996a, 78-79 for the analysis of Giton as Nisus.

15 C. Panayotakis $1995,112-14$ is indispensable reading for his discussion of the relation of the Satyrica to Roman mime. 
From mythological heroine to Vergilian hero to adulterous wife, Giton is certainly one of the most versatile drama queens of all time!

After losing Giton, Encolpius retires, Achilles-like, to sulk over the loss of his 'Briseis'. There, pondering the character of his faidlless love, he says (81.5):

quid ille alter? qui [tanquam] die togae virilis stolam sumpsit, qui ne vir esset a matre persuasus est, qui opus muliebre in crgastulo fecit, qui postquam conturbavit et libidinis suae solum vertit, reliquit veteris amicitias nomen et, pro pudor, tanquam mulier secutuleia unius noctis tactu omnia vendidit. ${ }^{165}$

What about the other one? On the day for the manly togal he put on a woman's dress and was convinced by his mother not to $b e$ a mann and did a woman's job in the slave-camp. After losing everything, and changing the foundation of his lusts, he - for shame! - like al nymphomaniacal female sold everything for a one night stand!

This assessment of Giton's gender is the most explicit description of his sexual nature. It is also a high sounding piece of moralizing and contains all the stock elements of the satirist's invective against mollitia: crossdressing, effeminacy, confusion of gender boundaries, and the crowning insult of being not just a mulier but a mulier sccutulein, a man-chasing nymphomaniac. It is also interesting to note that amid this confusion of gender Encolpius' diatribe echoes yet another genre becuuse, as noted since the times of Scaliger and Heinsius, the passige recalls Cicm ero's attack on Marc Antony (Phil. 2.44):

sumpsisti virilem, quam statin muliebrem togam reddidisti. primo vulgare scortum; certa flagitii merces nec en parva; sed cito Curio intervenit, qui te a meretricio quaestu abduxit et, tamquam stolim dedisset, in matrinonio stabili et certo collocavit.

You put on the manly toga, which you immediately changed into a wom an's dress. At first you were a common whore, and the price of your shane was fixed, nor was it cheap. But soon Curio stepped in and took you away from your occupation as a prostitute, and, as though he had given you a matronly dress, he set you up in a fixed and stable marringere.

Thus Cicero inveighs against Antony, the 'wife' of Curio, So Citon, many times compared to the heroines of legrend and epic, is also analom gous to a historical personage himself, the object of rhetorical gender=

16 Admittedly, the subject of Encolpius' rant appears confused, and, as Rirhlin 2009, 86 points out, it may not be exactly dear whedher we are to mulerseand the target to be Giton or Ascyltus or both. 
bending. In addition to seeing Giton cast as Jocasta, Nisus, and a Sabine woman, we may find him playing other mythic parts: Habermehl in his commentary to Petronius thinks that the phrase "qui ne vir esset a matre persuasus est' may be an allusion to Achilles, whose mother dressed him as a girl at the court of Lycomedes on Scyros. ${ }^{17}$ Habermehl also draws a parallel with the legacy-hunting mother at Sat. 140, who filium filiamque ingerebat orbis senibus ("foisted her son and daughter on childless old men'), acting as pimp for both son and daughter.

Encolpius' description of Giton at 81.5 is outrageously hilarious and accurate; mulier secutuleia is an utterly degrading term for a woman, and even more so when applied to a member of the male sex. ${ }^{18}$ It is striking then and perhaps inevitable given the game that Petronius is playing that the whorish, promiscuous Giton at one point elicits comparison to the supreme exemplar of Roman female chastity, namely Lucretia. Firsttime readers of Petronius, perhaps unaware of the author's penchant for parody, may be shocked and puzzled by the event in Sat.9, where Giton has just been the victim of an attempted rape by Ascyltus, who had come to him with drawn sword and said si Lucretia es ... Tarquinium invenisti ('If you are Lucretia, you have found your Tarquin')." Here in a parodic recreation of Livy 1.58, Ascyltus plays the role of Tarquin, Encolpius that of Collatinus, and Giton, of course, becomes Lucretia. Given Giton's sexual escapades throughout the narrative, comparison of this 'male' mulier secutuleia to the paragon of female virtue is outrageously provocative. Giton's description of the attempted rape is amusing in its use of feminine categories applied to himself: cocpit mihi velle pudorem extorquere ('he started to steal from me ny chastity'). Pudor is, of course, an important Roman value both for men and women, and Giton's attribution of this virtue to himself is a splendid piece of parody. Petronius' undermining of Roman foundational legend shocks, as it is indeed meant to do, but it does not surprise in light of the same treatment of Homer and Vergil.

1.7. Habermehl 2006, 42 ad loc.

18 Mulier secutuleia is rendered as 'groupie' by Richlin 2009, 86 and as 'läufiges Weib' by Habermehl ad loc.

19 Breitenstein 2009,121-35 provides an exhaustive and useful commentary on the entire episode of Sat. 9. 
Suffused as the Satyrica is with Vergilian reminiscences, it is inevitable that Giton must at some point become Dido. ${ }^{21}$ The equation with the queen of Carthage comes at Sat. 94.1, when Eumolpus exclanis: 'o felicem ... matrem tuam, quae te talem peperit; macte virtute esto' ('How fortunate...the mother who bore a child like you. Blessings upon you'). With this allusion to Aeneid 1.606, the epic language is, of course, fulsome. Also, Eumolpus' promise to exalt Giton in verse (ambrorem invenisti: ego laudes tuas carminibus implebo ('You have found a lover; I will fill your glory with poems'), like a Latin love elegist immortalizing his mistress is specious, coming as it does not only from a proven hack of a poet but also the shameless seducer of the Pergamene boy. Petronius' recollection of Dido at this juncture is in keeping with other instances of the Dido motif elsewhere in the novel. We recall that in the story of the widow of Ephesus, the Dido motif is used to sabotage the chastity of the matron, but perhaps the most shocking use or misuse of Vergil is at Sat. 132.11 when Encolpius, after a failed attempt at sex with Circe, re.bukes his unresponsive membrum virile and with a direct quotation from the Aeneid recalls Dido in the underworld at Acm. 6.469): illa (sc. mentula) solo fixos oculos aversa tenebat (it, [i.e., my member] turned away and kept eyes fixed on the ground'). Courtney calls this the wittiest joke in l'etronius, and Petronius' profanation of Vergil in the service of the crudest type of Priapeia says much about his exploitation of the classics for his own purposes. ${ }^{21}$

Parody of epic is also much present on the ship of Lichas. A good example is the famous or infamous recognition scene (115.9) where Li chas playing Eurycleia to Encolpius' Ulysses recognizes his sexual soulmate by a token far removed from Homer. In addition to epic, however, the romance novel also plays an influential role in the Sitlyriat. Al-m though the question of Petronius' relation to the romance novel is a much vexed one, complicated by the loss of many novels as well as the insecure dates of writers like Chariton, Xenophon of Ephesus, and Achilles Tatius, it is evident that the Satyrica shares many aftinitics with Greek romance. ${ }^{22}$ Its use of dreams, shipwrecks, courtroom

20 C. Panayotakis 2009,52 says 'It is not surprising that the lion's share of hiterury evocations in Petronius belongs to Virgil'. This is certainly true given the pluce

21 Courtney $2001,199$.

22 For discussion of Petronius' relation to the Greek novel see ]. R. Morgan 20m4, $40-46$ and C. Panayotakis 2009, 58-60. 
dramas, threats to chastity, suicide attempts, and laments in the tragic mode comprises many parallels to the stock ingredients of the extant novels. Also, the adventures of Encolpius and Giton themselves mirror those of heroes and heroines like Habrocomes and Antlia or Clitophon and Leucippe. In his attractiveness to all who encounter him, Giton is comparable to the heroines of the novels except, of course, for chastity, despite his claim to pudor in the Lucretia allusion, while, as masculine hero, he finds identification with, for example, Odysseus at Sat. 98.5. Petronius even assigns to him an aristeia on an epic scale in the fight that takes place on the ship of Lichas. This ship-board battle is a vulgat: brawl, but like the 'tragedy' in the taberna it takes on epic color (108.9): nihilo minus tamen perseverat dimicantium furor, illis pro ultione, nobis pro vita pugnantibus. multi ergo utrimque sine morte labuntur, phures cruenti vulnepibus referunt veluti ex proelio pedem, nec tamen cuinsquam ira laxatur ('No less did the fury of the combatants persist, with them fighting for revenge and us for our lives. On both sides many fell without fatalities, and still more retreated with bloody wounds, and yet no one's rage abated'). Comparing the passage to one in Sallust (Ing. 94.5) and to a scene in Chariton (6.2.2), Courtney stresses the momentousness of the battle as described by Petronius. ${ }^{23}$ At its climax and center stands Giton, who, while evoking Helen being fought over by Greeks and Trojans as well as the heroines of Greek novels desired by competing rivals, suddenly takes a heroic masculine turn, being described in the fray of battle as fortissimus Giton (108.10). When in the next breath we learn that the climax of these battlefield heroics is Giton's threat to castrate himself, the effect is one of stumning incongruty. For Giton, to go from epic hero about to save the day on the field of battle now to become a etmuch like Attis in the service of Cybele is a notion that only Petronius could imagine. Fortunately, this does not happen, and Tryphaena greatly relieved throws off a poem with allusions to yet more analogues to Giton, namely Helen and Medea. The hero of the day, however, is bald, and so Tryphaena gives him a girlish wig and beautifies his eyes with mascara. In this scene, we may well have an allusion to Odysseus, whose temporary baldness Athena had restored, but also to Ovid's Corinna, who in Amores 1.14, went bald from dying her hair and had to resort to a wig. The capillorum elegidarion at 109.9 indicates we have yet

23 Courtney 2001, 164. 

another genre operative in the characterization of Giton, Latin love
elegy. ${ }^{24}$

Giton's evocation of the heroes and heroines of epic, tragedy, elegy, romance novel, and history is but one indication of Petronius' mastery of the grand genres of literature antecedent to the time of Nero. But what of the Satyrica's relation to real life, especially the connection of gender to tragedy and performance art of the $60 \mathrm{~s}$ CE? The emperor himself entertained high poetic ambitions, and, if Sullivan is correct in positing a literary feud between Petronius and the two Amnaci, Seneca and Lucan, literature in the court of Nero was a deadly serious business, sometimes in the literal sense. ${ }^{25}$ Obsessions with literature as well als theatricality - theatricality often of a sexual nature - are hallnarks of the Age of Nero and leap out at us from the pages of Suetonius, 'Ticitus, and Dio Cassius. For example, we read in the Suctonian life (21):

tragoedias quoque cantavit personatus heroun deorumgluc, item heroidum ac dearum, personis effectis ad similitudinem oris sui et feminac, prout quamque diligeret. Inter ceteral cantavit Canacen parturicntem, Oresten matricidam, Oedipodem excaecatum, Herculem insanum.

He (Nero) sang in tragedies, taking the parts of heroes and gods, sometimes even of heroines and goddesses, wearing masks cither modcled on his own face, or on the face of whatever womin he happened to be in love with at the time. Among his performances were Comace in Clildhirth, Orestes the Matricide, Oedipus Blinded, and The Madness of Hercules.

The gender-bending theatricality of Nero, playing both heroes and heroines, spilled over into real life, and one can only imigine the reaction of the audience seeing the princeps on stage as the pregnant Canace or in the guise of Poppaea, as Dio tells us (63.28.5). Even at the moment of death Nero, we are told, recited a poetic snippet from his Oedipus, and at the point of driving the dagger into his throat he summoned at quom tation from the lliad. As for the emperor's sex life, its polymorphous straddling of gender roles has been notoriously documented by Suctonius and Tacitus. Although, given the nature of political slander, con temporary gossip and authorial bias, the historicity of some of the sensitional allegations about the emperor may be open to question, still the Nero of popular imagination has much in common with the ethos of the Satyrica. For apart from Nero's wives and concubines and his rape of a Vestal Virgin (Suet. Ner, 28) as well as his violation of Britannicus

24 Courtney 1991, 28-29.

25 Sullivan 1968b. See also Vout $2009,101-13$. 
(Tac. Ann. 13.17), there is the account of Nero's marriage to Sports, whom, says Suetonius, Nero had castrated, then married in a formal wedding ceremony, and treated as a wife. This lurid episode is matched by Tacitus' account of Nero's marrying the male Pythagoras also in a formal wedding ceremony but this time with the emperor as bride (Ann. 15.37). Finally, there is Petronius' famous death-bed missive to Nero (Tac. Anm.16.19). Written consciously as a literary and philosophical parody of Socratic and Stoic death scenes, Petronius' last message to the emperor included a catalog of the flagitia principis sub nominibus exoletorum feminarumque et novitatem cuinsque stupri ("the outrages of the emperor along with the names of his women and male partners as well as the novelty of each sex act'). The mention of exoleti, males (usually prostitutes) who penetrated adult males, of course, carries the inplication that Nero assumed the role of cintedus or pathic and, thus, is the ultimate insult to his manhood. "We may ask with Courtney, "Where is the boundary between fantasy and reality here? ${ }^{27}$ It is clear that the Satyrica consciously blurs that boundary by its juxtaposition of the sublime with the picaresque and of the literary with the quotidian. The brilliant dissonance of the novel mirrors the obliteration of the distinctions of gender and genre, while the intersection of the real and the ideal is a vehicle for the self-satire that informs the characterization of Encolpius as well as the public and private personas of the Arbiter's emperor. In the end, what the historians have to say about Nero's sexual and artistic milieu is not that far removed from the world of the Satyrica, and, when it comes to gender and genre, we may profitably read Tacitus' Amiales and Suetonius' Vita Neronis as texts parallel to Petronius' novel. ${ }^{28}$

26 For a discussion of exoleti with reference to their relation to Nero see Williams $1999,83-86$.

27 Coutney 2001,219 has an interesting discussion of the theatricality of many of onian narratives in Suetonius, Tacitus, and Dio Cassius.

28 In writing this paper I owe a debt of gratitude to Froma Zeitlin and especially to Marilyn Skinner for their insightful suggestions. Any deficiencies are, of course, my own. 